PSICOLOGÍA

IBEROAMERICANA
Psicología Iberoamericana ISSN: 1405-0943

revista.psicologia@ibero.mx

Universidad Iberoamericana, Ciudad de México México

\title{
Evidence-based psychology in times of COVID in Mexico
}

\section{Camacho Gutiérrez, Everardo}

Evidence-based psychology in times of COVID in Mexico

Psicología Iberoamericana, vol. 29, núm. Esp.3, e293415, 2021

Universidad Iberoamericana, Ciudad de México, México

Disponible en: https://www.redalyc.org/articulo.oa? id=133968747001

DOI: https://doi.org/10.48102/pi.v29i3.415

\section{(c) (1)}

Esta obra está bajo una Licencia Creative Commons Atribución 4.0 Internacional. 


\section{Editorial}

\section{Evidence-based psychology in times of COVID in Mexico}

Psicología basada en la evidencia en tiempos del covid en

México

Everardo Camacho Gutiérrez ecamacho@iteso.mx Instituto Tecnológico y de Estudios Superiores de Occidente (ITESO),

México

https://orcid.org/0000-0002-8592-7897

Psicología Iberoamericana, vol. 29, núm. Esp.3, e293415, 2021

Universidad Iberoamericana, Ciudad de México, México

DOI: https://doi.org/10.48102/ pi.v29i3.415

Redalyc: https://www.redalyc.org/ articulo.oa?id=133968747001
The rates of knowledge production in Latin American countries are much lower when compared to Anglo-Saxon and first world countries (VeraVillarroel et al., 2011). In part, this difference is explained by the financial support that the governments of wealthier countries allocate to research. Mexico has not yet been able to retain 1\% of GDP for the development of science and technology (Torres-Samuel et al., 2020). Given these conditions, Mexican scientists do what they can, on the understanding that many phenomena in Mexico that should be studied is often not and local research is lacking. The consequence of this trend is that much of our research comes from abroad, as well as the technology that derives from that knowledge. We are great consumers of this knowledge which to us comes at a high cost and this knowledge is often not adapted to our cultural conditions in Mexico. Even when we try to standardize the sociocultural conditions in research from abroad, this presents a challenge because these Western sociocultural conditions still do not suit the sociocultural conditions of Mexico.

Another consequence linked to the scarcity of knowledge production in Mexico is that the authorities responsible for public policy do not have a tradition of basing their decision-making on research and scientific knowledge.

The COVID-19 pandemic arrived in the world 18 months ago to disrupt the daily lives of millions of people, and one of the few certainties we have about it is that the restrictive methods to prevent the spread of the virus and the potential threat of the virus will continue and it will be a long time before the pandemic will be resolved, which is not a simple task (OPS, 2020).

In many countries across the world, research projects have been developed to learn more about the pandemic. This has been done to better understand COVID-19 and its effects on the population, to develop effective and efficient public policies around the pandemic. 
One of the most important effects of the pandemic is based on lifestyle changes, which has directly impacted the mental health of large sectors of the population. This has consequences for our relationships, working lives, physical health, the ability to adapt to threatening situations, our emotional health and overall quality of life (Larios-Navarro et al., 2020; Ribot Reyes et al., 2020).

Under normal conditions, mental health has not traditionally been a priority in most societies, however, it has acquired a certain level of relevance and importance during the pandemic. Furthermore, the vulnerability of large sectors of the population are attracting more attention and preventative strategies and interventions targeting these individuals are being developed (Mariscal, 2020). The World Health Organisation (WHO) asserts that we will be feeling the effects of the psychosocial impact of the COVID pandemic for at least three years following the end of the pandemic (González García \& Ramírez Nardiz, 2020).

Under these different circumstances, the evidence-based psychology movement (Mustaca, 2011) stands out as an important and relevant perspective that guides the development of applied research and allows the development of both diagnostic and intervention strategies that seek to be effective and can be applied to groups of the population in a proven and generalizable way.

Currently, little is known about the direct and indirect impact on the population by the COVID-19 pandemic. We know that the psychosocial impact on the population has affected various areas. Therefore, it is very relevant to build knowledge in our country about the phenomenon and research how it impacts mental health, well-being, and the quality of life of the population.

From the perspective of a professional in the field of psychology, orientated towards analyzing the psychosocial dimensions and their contribution to research, the analysis of multiple people is required to generate knowledge about our context. This allows, in a limited context, the possibility of developing clear diagnoses and creating innovative preventive interventions during the pandemic. For example, the use of computerized technology that we have been using to communicate with each other and maintain social distancing has helped improve the quality of life of many people during the pandemic, as well as prevent the spread of COVID-19.

This has made it possible for colleagues from all over the country, and others from abroad, to collaborate from their perspectives and synthesize their work so that a melting pot of knowledge can be generously constructed. Through this synergy, we gain an integrated perception of the pandemic by assembling the various pieces that make up this puzzle. Perceiving what is not apparent, assessing the images that emerge when a photograph is developed and describing the dynamic movement of a phenomenon that never stops and is unique is challenging but has been achieved by all the authors in this special issue. 
This is how this special issue of Psicologia Iberoamericana has been put together. It provides unique and objective information about different microcosmos, with diverse populations, from university, secondary and preschool students from different contexts to university workers to relatives of people sick with Covid, who live with feelings of fear and grief, from communities with limited access to resources to neighbourhoods with high socioeconomic levels. The special issue reflects on the experience of families in Mexico during the pandemic, telephone services available and larger groups such as communities and neighbourhoods. It also analyses information on mass media and media networks, rumours and the disinformation process.

This information is transformative to the extent that it is knowledge generated in the context of our own country, from our own physical and spatial conditions, as well as being culturally important and is useful for both specialists and people who make decisions at the public health level.

This issue represents a contribution of systematized and objective knowledge, which could potentially transform the reality of other countries and help improve the living conditions of many during the pandemic.

\section{References}

González García, A., \& Ramírez Nárdiz, A. (2020). Análisis y reflexiones sobre el COVID-19: pandemia y postpandemia. J. M. Bosch editor.

Larios-Navarro, A., Bohórquez-Rivero, J., Naranjo-Bohórquez, J., \& SáenzLópez, J. (2020). Impacto psicológico del aislamiento social en el paciente comórbido: a propósito de la pandemia COVID-19. Revista Colombiana de Psiquiatria, 49(4), 227-228. https://doi.org/10.1016/j.rcp.2020.07.0 02

Mariscal, S. M. A. C. (2020). La salud mental ante la pandemia de la covid-19. Pluralidady Consenso, 10(44), 128-135.

Mustaca, A. E. (2011). Evaluación objetiva de los tratamientos psicológicos: modelos basados en la ciencia. Revista Colombiana de Psicología, 20(1), 99-106.

Organización Panamericana de la Salud [OPS]. (2020). La OMS caracteriza al COVID-19 como una epidemia. https://www.paho.org/hq/index.php?op tion=com_content\&view $=$ article\&id=15756:who-characterizes-covid19-as-a-pandemic\&Itemid $=1926 \&$ lang $=$ es

Ribot Reyes, V. D. L. C., Chang Paredes, N., \& González Castillo, A. L. (2020). Efectos de la COVID-19 en la salud mental de la población. Revista Habanera de Ciencias Médicas, 19(1).

Torres-Samuel, M., Vásquez Stanescu, C. L., \& Crissien Borrero, T. J. (2020). Eficiencia técnica de la investigación y desarrollo, ciencia y tecnología, educación e innovación en países Latinoamericanos. RISTI-Revista Iberica de Sistemas e Tecnologias de Informacao, E29(5), 582-594.

Vera-Villarroel, P., López-López, W., Lillo, S., \& Silva, L. M. (2011). La producción científica en psicología latinoamericana: un análisis de la investigación por países. Revista Latinoamericana de Psicología, 43(1), 95-104. http://dx.doi.org/10.14349/rlp.v43i1.613 